\title{
Utilization of Location-Based Services Using Augmented Reality Perception Method for Android Based School Search
}

\author{
Kiswanto, Elly Yanuarti, Benny Wijaya, Laurentinus, Supardi, Agustina Mardeka Raya \\ Institut Sains dan Bisnis Atma Luhur Pangkalpinang, Indonesia \\ kiswanto@atmaluhur.ac.id, elly@atmaluhur.ac.id, bennywijaya@atmaluhur.ac.id, laurentinus@atmaluhur.ac.id, \\ supardi@atmaluhur.ac.id, agustinamardekaraya@atmaluhur.ac.id
}

Submitted : Nov 18, 2021 | Accepted : Jan 3, 2022 | Published : Jan 5, 2022

\begin{abstract}
Data technology has become the main means for activities in various sectors of life, one of which is location-based services for SMA/SMK schools in the Bangka Belitung area. By using a location-based service application, it is expected to be able to overcome the problem of finding the position of SMA/SMK in the Bangka Belitung area. In this study, we would like to discuss the search for SMA/SMK positions. Through the push, Location-Based Service will be displayed in the smartphone, which will help identify the presence of the school's position on the smartphone. The result of the application that is formed is an Android-based application that can recognize the presence of SMA/SMK positions. This study aims to create a location-based service application that is combined with the concept of overlaying geographic position information from augmented reality perception, which is one type of augmented reality. The overall application quality test results include 1). Based on the Functionality aspect, the percentage of the actual score got a total score of $91.8 \%$. 2). Based on the aspect of reliability, the percentage of the actual score got a total score of 97.6\%. 3). Based on the Usability aspect, the percentage of the actual score gets a total score of $92.2 \%$.4). Based on the aspect of efficiency, the percentage of the actual score gets a total value of $76.5 \%$. 5). From the calculation of the total score in percent is $89.5 \%$. So based on the total score in percent, it can be concluded that the overall application quality test results are $89.5 \%$, so the prototypes produced in this study are included in very good criteria.
\end{abstract}

Keywords: Location-Based Services, Augmented Perception Reality, Augmented Reality, GPS, Mobile Android

\section{INTRODUCTION}

The development of information technology today is rapidly entering various fields, so that many new technologies are emerging especially in the IT world (Susanty et al., 2019). One of them is Location-Based Services (LBS) technology, the main feature in the use of cellular phone technology (cellphones) so that it offers many advantages for its users. The popularity of smartphones these days has brought major changes to the features of these services, and as a result, the LBS application has emerged as a generation of 'killer apps ( Iwan Faizal, (2015). Desktop or mobilebased LBS applications are broadly useful in providing relevant content for users, especially online guide applications that will benefit traveling connoisseurs. All of these things make LBS a technology that combines three technologies: information and telecommunications technology (ICT), mobile telecommunications systems, and geographic information systems (GIS) (Iwan Faizal, 2015). Along with the high level of mobility, the last few years are booming mobile device or mobile device. One of the fastest mobile devices is Smartphones are the genre of smartphones where almost everyone has one nowadays. a mobile phone that was originally as a means of communication, is now more than its basic function. Various kinds of features have been implanted, in terms of images, videos, cameras, internet, or document processing as an appropriate PC device. This can not be separated from the embedded operating system

*name of corresponding author

This is an Creative Commons License This work is licensed under a

Creative Commons Attribution-NonCommercial 4.0 International

License. 
found on mobile phones make it a smartphone mobile device (Budiman, 2016). The Assisted Global Positioning System (A-GPS) is a development of the regular GPS as a positioning device. which in positioning does not only rely on signals from GPS satellites but gets assists from a data server, namely the cellular operator. Assistance in the form of position data taken based on LBS (Location Based Service), is a location determination system based on BTS (Base Transceiver System). Location data that is not only sent using satellite is also assisted by data from the server which is conveyed to A-GPS via a data connection via GPRS or 3G so that positioning is faster or also known as Time To First Fix (TTFF) and is more accurate thanks to the help of data servers operator (Juansyah, 2015). LBS is a service to provide information that is stored in a database. This information can be created, organized, selected, or filtered to provide information about the location information of the mobile user. Considering that information services are now a must, LBS allows us to find the geographic location of the mobile device we use using GPS coordinates (latitude and longitude). As a result, various applications are now emerging that offer information maps online. Apart from mobile phones, LBS can be accessed using computers and other mobile devices such as laptops, portable navigation devices, and embedded systems via the Over The Air (OTA) network, making it easier for users to access various services. This includes user location information that can be used to add value to the overall service (Iwan Faizal, 2015). The study aims to combine LBS and AR in an android-based mobile phone device by manipulating virtual objects into real objects through the camera as input and the mobile phone screen as output (Imansyah \& Widiastuti, 2017). Currently, there are location-based applications (LBS) that have been studied by several people, but the author will design location-based applications (LBS) with differences and improvements from the functional side to existing applications (çimen, 2021). Based on the problems above, to help students who want to continue their education at the SMA (High School) and Vocational High School (SMK) levels in obtaining information about SMA/SMK on Bangka Island, a SMA/SMK search application was built Android-based SMK. In this research, system testing uses 4 characteristics, namely Functionality, Reliability, Usability, and Efficiency. The number of respondents in this testing process there are 50 respondents. Respondents' Responses Based on Functionality Aspects, from the calculation of the total score in percent is 91.8 percent. Respondents' Responses Based on Reliability Aspects, from the calculation of the total score in percent is 97.6 percent. Respondent Responses Based on Usability aspects, from the calculation of the total score in percent is 92.2 percent. Respondents' Responses Based on Efficiency Aspects, from the calculation of the total score in percent is 75.5 percent.

\section{LITERATURE REVIEW}

Location-Based Service Location Based Service is a service on a mobile phone or another mobile device that depends on the location of the device. By using location-based services, the device determines its location, and this information is used to obtain other useful information for the user (Rokhman \& Nugroho, 2013). Augmented reality is a combination of real and virtual objects in a real environment, running interactively in real-time, and there is integration between objects in three dimensions, namely virtual objects integrated into the real world. Augmented reality can be applied to Android mobile device applications because the augmented reality system analyzes real-time objects captured in the camera which can be implemented on devices that have GPS, accelerometer, compass, and camera (Jamal \& Susanto, 2012).

Below you can see research that has been done by other researchers using location-based service methods:

1. The development of the school in Cullinan is very rapidly both public and private, many schools by themselves the criteria for each major, either high school or other vocational school in Cullinan. High rapid development schools, middle and elementary schools with geographical location the forms that exist in Cullinan have an impact on the search for information school location. So that people can easily find the location of the school according to the desired criteria, so at this writing an application is made to search for school location using android-based mobile. With this application, users get the convenience expected in searching for information school or find information about the school at question(Marlinda, 2016).

2. This application was created so that it is easy for the public to find out the location of the school closest to where the user is located. In making this application, using Java programming language and using Android. Android OS is flexible because the Android OS can be used on many hardware platforms and is easy to use its usage. In this application using the location based service method (LBS) which can provide user location information with geographic position school via mobile devices with the help of using the google API application and google maps accessed by internet connection. This application uses technology the latest, it is hoped that it can advance education in Jogjakarta and can make it easier for the public to find information about schools and pre-school facilities(裕作 et al., 2011).

*name of corresponding author

This is an Creative Commons License This work is licensed under a

Creative Commons Attribution-NonCommercial 4.0 International

License. 
3. Location-based information services (Location Based Service/LBS) have become a necessity accompanying people's daily activities in presenting accurate information, especially for people who need certain information in urgent conditions. Resources Information about hospitals is very necessary to know the availability of facilities in hospitals, especially about doctors and diseases that can be treated. In its function as a supporter of GPS services (Global Position System) in searching for a place or location, LBS supports system functions information and hospital routes built in this study. In the system built, the information about the hospital provided includes address, telephone number, e-mail, website, the name of the doctor and the disease being treated, as well as the route to the hospital(Kasih \& Harini, 2018).

4. This research presents a solution to raise awareness of society towards the nation's culture through a location-based service application system with mobile devices. With this application, one will be able to know the culture based on their location of existence and also provide information about some places that may not have been registered in the system. Determination of the location can be taken advantage of by the GPS facilities found on Android mobile devices. This matter This is done so that the community can continue to preserve the history and culture of the Indonesian nation(Fauzi, 2015).

5. In this study, an application will be developed on devices with the Android operating system that can locate public facilities around users by utilizing location-based service technology. This application utilizes data from Foursquare. The test results of the built application show that the data filter and auto check-in system are running well so that data duplication in Foursquare can be used minimized(Rokhman \& Nugroho, 2013).

6. Mobile Location-Based Service Application Design for boarding houses in Semarang Based on Android, it is a client-server application created using Java, PHP, jQuery, and MySQL databases. Intake in the form of latitude and longitude coordinates utilizing the GPS feature on mobile devices and will be displayed on the Google Maps API. The result of designing this application is the realization of an application that can find boarding locations based on the Android operating system, with features that can help users find boarding positions. This application can help boarding house owners to promote their boarding information to users. The design also introduces the development of android applications using the Global Positioning System function for user navigation(Iqbal et al., 2015).

\section{Research Design}

\section{METHOD}

The researcher's plan will be use as a guide for the progress of the research (Widiani et al., 2018)

This study intends to describe and select the concepts and theories needed for overlaying data on a mobile device camera preview. The purpose of this research is to explore by experiment, what steps and methods are needed in the process of overlaying the data. Based on the objectives, the method chosen is an experimental research method.

The result of this research is a prototype of a location-based service application program that displays POI data according to the last location of the mobile device. Then display this POI data as a virtual object. This study aims to implement existing concepts for the development of prototypes, instead of examining the possibility of new theories and concepts, this research uses applied methods.

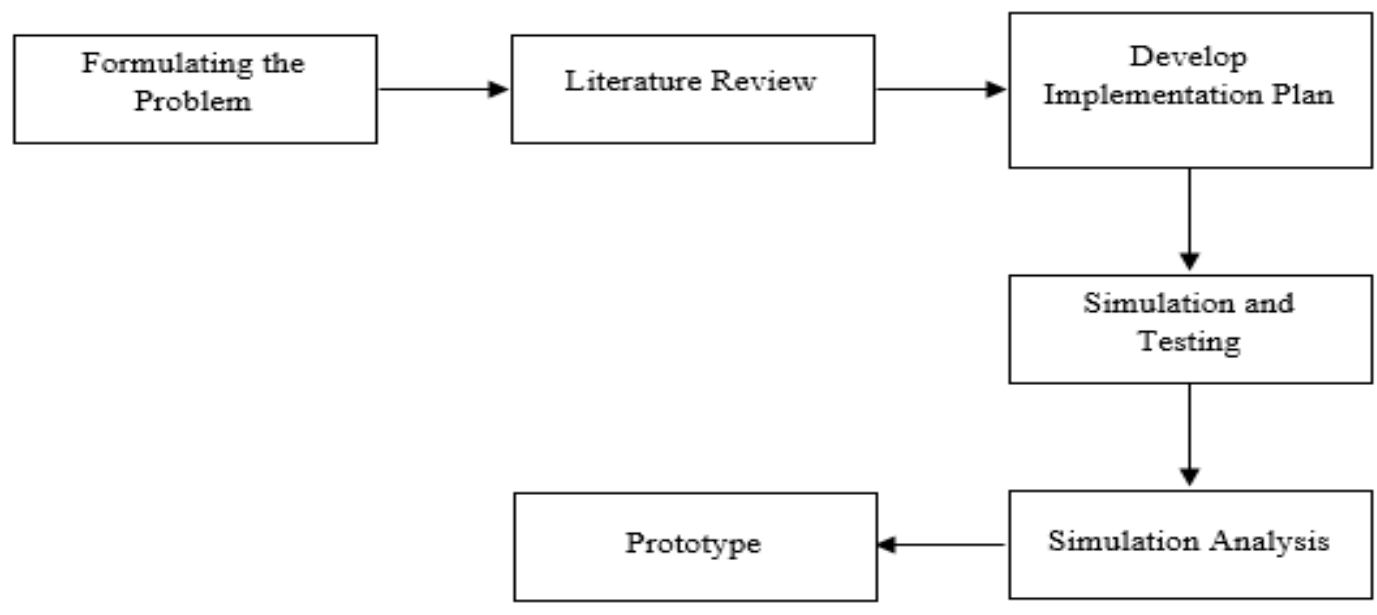

*name of corresponding author

This is an Creative Commons License This work is licensed under a

Creative Commons Attribution-NonCommercial 4.0 International

License. 
Fig 1. Research Steps

Algorithm Analysis Stage

For this stage of the process will be described in figure 2

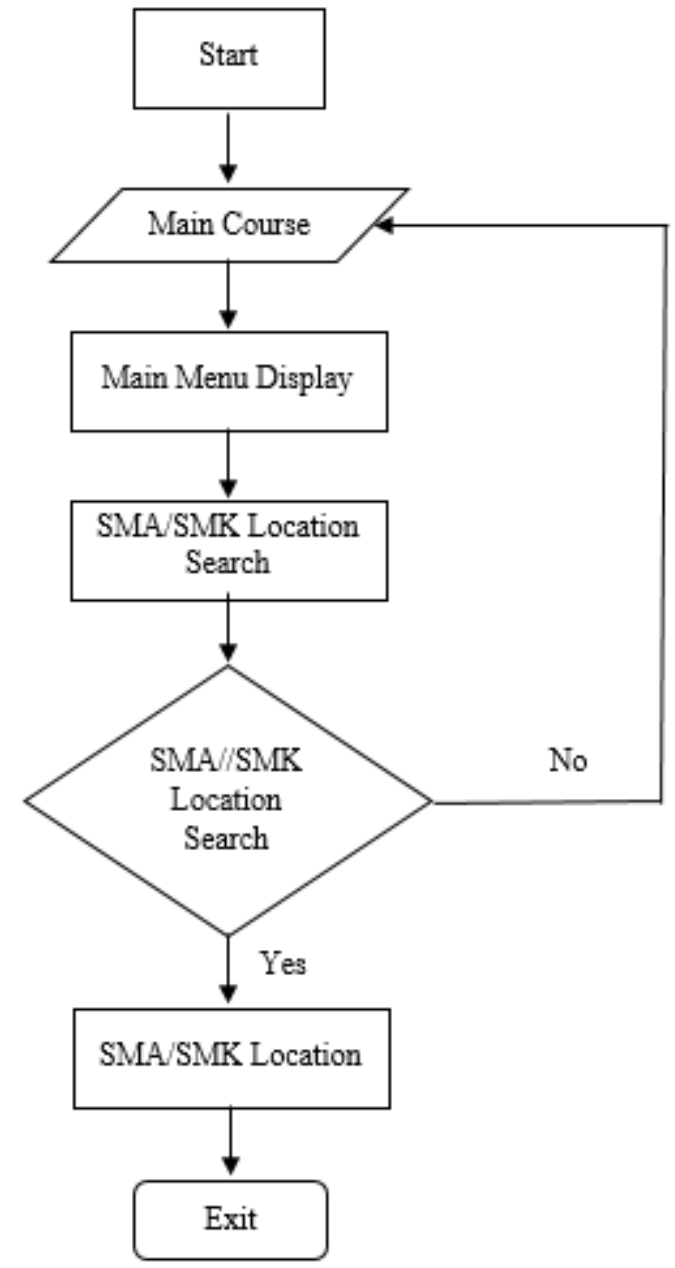

Fig 2. Flowchart of the system flow method

\section{Location-Based Services}

Location-based services provide users with the ability to know the user's location. Furthermore, this locationbased service provides spatial information on the user's location. Users are also given the ability to interact with the system.

\section{Augmented Reality}

Augmented reality (AR) is a variation of a virtual environment (VE) or virtual reality. But VE puts users into a synthetic environment. Where the user cannot see the real world while inside the VE. Not with AR, in AR, VE is just an addition to the real world. In addition to adding objects to the real environment, AR can also remove objects in the real environment. Ar application is not only in the sense of sight, but can also be used as a supplement to the sense of hearing. AR systems can be divided into two basic categories, namely the mobile system category and the fixed system category. In addition, AR systems can also be divided into two basic functions, namely:

a. Augmented Perception of Reality (APR): Perception is the awareness of elements of the environment through

physical sensations. Here AR serves to improve the user's perception of the surrounding environment through

physical sensations. APR increases the user's understanding of the surrounding environment, so as to improve *name of corresponding author 
decision-making or action skills. An example is an augmented location based system developed by wikitude or the screen, to understand our position in the surrounding environment based on appropriate point of interest data.

b. Forming a new artificial environment: Here AR is able to add objects that are no longer in the real environment. For example, showing a building that has collapsed or does not exist, by forming a 3D object of the building in question.

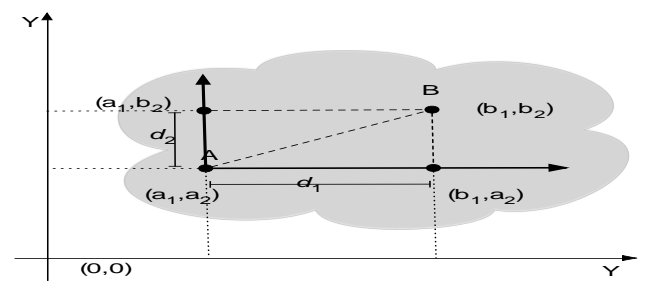

Fig 3. Move Origin Points from the Coordinate Axis

\section{Coordinate Axis Origin Point Transfer}

Drawn 2 depicts two points A and B. If point B wants to be declared as the cold point of origin of the A coordinate axis, then to do so it is necessary to find the distance between point $A\left(a_{1}, a_{2}\right)$ and point $\left(b_{1}, a_{2}\right)$ or $d_{1}$. Then the distance between point $A\left(a_{1}, a_{2}\right)$ and point $\left(a_{1}, b_{2}\right)$ or $d_{2}$. The values $d_{1}$ and $d_{2}$ will be the new point of $B$, i.e. point $B$ with the origin axis at point $\mathrm{A}$.

$$
d_{1}=\sqrt{\left(b_{1}-a_{1}\right)^{2}+\left(a_{2}-a_{2}\right)^{2}}
$$

and

$$
d_{2}=\sqrt{\left(a_{1}-a_{1}\right)^{2}+\left(b_{2}-b_{2}\right)^{2}}
$$

\section{Viewpoint}

Viewpoint is the angular range of a field. From figure 4. The derivable formula for the point of view is as follows:

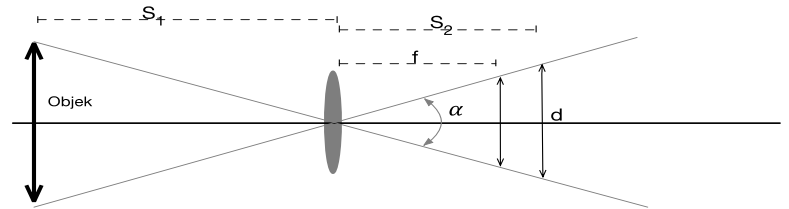

Fig 4. Viewpoint

In figure $f$ is the focal length of the lens, $S_{1}$ is the distance of the lens to the object, and $S_{2}$ is the distance of the lens with the shadow of the object. While $\alpha$ is the angle of view of the shadow of the object, and $\mathrm{d}$ is the height of the shadow.

Using the fundamental theorem of trigonometry, it was found that:

$$
\tan (\alpha / 2)=\frac{d / 2}{S_{2}}
$$

We can solve the value of $\alpha$ by providing:

$$
\alpha=2 \tan ^{-1} \frac{d}{2 S_{2}}
$$

For a considerable distance of $S_{2}$, the formula can be simplified by assuming that $S_{1}=f$. So that the formulation of $\alpha$ can be re-written into:

$$
\alpha=2 \tan ^{-1} \frac{d}{2 f}
$$

The value $\alpha$ is used as a scale factor for an object with the value $d$ being a predefined constant. On a camera, the $d$ value is the size of the film or the size of the camera sensor. In the use of Augmented Reality here, the value $d$ is selected based on the experiment, to choose the most appropriate value. Examples of use, if a virtual object is circular, then the value of $\alpha$ used as a factor scale for the radius of the circle:

*name of corresponding author

This is an Creative Commons License This work is licensed under a

Creative Commons Attribution-NonCommercial 4.0 International

License. 


$$
r=\alpha \cdot h
$$

Where:

$r$ : Radius of the circle

$\alpha \quad$ : Scale factor

$h \quad$ : Height of mobile devices

\section{Projection of the point of one field}

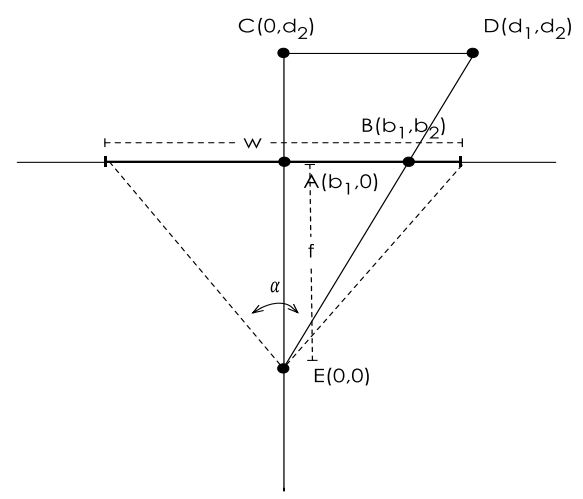

Fig 5. Projected point $D$ becomes point $B$ on the width plane $w$

The projection of the point of one image field is the same thing as the projection of objects or objects in our eyes when looking at objects, or cameras pointing at an object. But unlike the projection of the point on the eye or camera lens, the field of the object is placed in front of the lens of view (Figure 5).

From the side-splitter triangle theorem, it states that if a triangle is $\mathrm{ECD}$, and the line $\mathrm{AB}$ is drawn parallel to the line CD (Fig. 5), then:

$$
\frac{E A}{E C}=\frac{A B}{C D}
$$

If for example the point $D\left(d_{1}, d_{2}\right)$ is known, point $B\left(b_{1}, b_{2}\right)$ is the point to be searched, the above formula is changed to:

$$
\begin{gathered}
\frac{f}{d_{2}}=\frac{b_{1}}{d_{1}} \\
b_{1}=d_{1} \frac{f}{d_{2}}
\end{gathered}
$$

If the projection plane has a width $w$ and the observer's point of view has a width $\alpha$, then it is assumed that the observer is at point $E$; then $f$ can be found with the following formula derivatives:

$$
\tan (\alpha)=\frac{w / 2}{f}
$$

Then the above formula can be expressed by:

$$
f=\frac{w / 2}{\tan (\alpha)}
$$

Where:

$f \quad$ : focal length, the distance between the observer and the screen of the mobile device.

$w \quad:$ The screen width of the mobile device.

$\alpha \quad$ : Observer's point of view

\section{Application Quality Level Per Aspect}

\section{RESULT}

*name of corresponding author

This is an Creative Commons License This work is licensed under a

Creative Commons Attribution-NonCommercial 4.0 International 
In this research, system testing uses 4 characteristics, namely Functionality, Reliability, Usability, and Efficiency. The number of respondents in this testing process there are 50 respondents.

Table 1. Respondents' Responses Based on Functionality Aspects

\begin{tabular}{|c|c|c|c|c|c|c|c|}
\hline \multirow{3}{*}{$\begin{array}{l}\text { Answer } \\
\text { Criteria }\end{array}$} & \multirow{3}{*}{ Weight } & \multicolumn{5}{|c|}{ Functionality } & \multirow{3}{*}{ Total } \\
\hline & & Suitability & Compliance & Accuracy & Security & Interoperability & \\
\hline & & 1 & 2 & 3 & 4 & 5 & \\
\hline Strongly agree & 5 & 25 & 24 & 38 & 12 & 26 & 625 \\
\hline Agree & 4 & 25 & 24 & 12 & 25 & 24 & 440 \\
\hline Nervous & 3 & 0 & 2 & 0 & 12 & 0 & 42 \\
\hline Disagree & 2 & 0 & 0 & 0 & 1 & 0 & 2 \\
\hline $\begin{array}{l}\text { Strongly } \\
\text { Disagree }\end{array}$ & 1 & 0 & 0 & 0 & 0 & 0 & 0 \\
\hline \multicolumn{2}{|c|}{ Number of Respondents } & 50 & 50 & 50 & 50 & 50 & 250 \\
\hline \multirow{2}{*}{\multicolumn{2}{|c|}{ Actual Score }} & 95 & 92 & 98 & 78 & 96 & 459 \\
\hline & & 100 & 100 & 100 & 100 & 100 & 500 \\
\hline
\end{tabular}

$$
\% \text { Total Score }=\frac{459}{500} \times 100=91,8 \%(\text { Very Good Criteria })
$$

From the calculation of the total score in percent is 91.8 percent. Based on the total score in the above percent, it can be concluded that 91,8 percent respondents have considered that the software developed as a prototype is reliable.

Table 3. Respondents' Responses Based on Reliability Aspects

\begin{tabular}{|c|c|c|c|c|c|}
\hline \multirow{2}{*}{$\begin{array}{c}\text { Answer } \\
\text { Criteria }\end{array}$} & Weight & Maturity & $\begin{array}{c}\text { Fault } \\
\text { Tolerance }\end{array}$ & $\begin{array}{c}\text { Recovera } \\
\text { bility }\end{array}$ & \multirow{2}{*}{ Total } \\
\cline { 2 - 5 } & & $\mathbf{1}$ & $\mathbf{2}$ & $\mathbf{3}$ & \\
\hline Strongly agree & $\mathbf{5}$ & 48 & 25 & 50 & 615 \\
\hline Agree & $\mathbf{4}$ & 2 & 25 & 0 & 108 \\
\hline Nervous & $\mathbf{3}$ & 0 & 0 & 0 & 0 \\
\hline Disagree & $\mathbf{2}$ & 0 & 0 & 0 & 0 \\
\hline $\begin{array}{c}\text { Strongly } \\
\text { Disagree }\end{array}$ & $\mathbf{1}$ & 0 & 0 & 0 & 0 \\
\hline Number of Respondents & 50 & 50 & 50 & 150 \\
\hline \multicolumn{2}{|c|}{ Actual Score } & 98 & 95 & 100 & 293 \\
\hline \multicolumn{2}{|l|}{ Ideal Score } & 100 & 100 & 100 & 300 \\
\hline
\end{tabular}

From the calculation of the total score in percent is 97.6 percent. Based on the total score in the above percent, it can be concluded that 97.6 percent of respondents have considered that the software developed as a prototype is reliable.

Table 4. Respondent Responses Based on Usability aspects

\begin{tabular}{|c|c|c|c|c|c|c|}
\hline \multirow{3}{*}{$\begin{array}{l}\text { Answer } \\
\text { Criteria }\end{array}$} & \multirow{3}{*}{ Weight } & \multicolumn{4}{|c|}{ Usability } & \multirow{3}{*}{ Total } \\
\hline & & $\begin{array}{c}\text { Understan } \\
\text { ability }\end{array}$ & Learnibility & Operability & Attractiveness & \\
\hline & & 1 & 2 & 3 & 4 & \\
\hline Strongly agree & 5 & 49 & 47 & 47 & 42 & 925 \\
\hline
\end{tabular}

*name of corresponding author

This is an Creative Commons License This work is licensed under a

Creative Commons Attribution-NonCommercial 4.0 International

License. 


\begin{tabular}{|c|c|c|c|c|c|c|}
\hline Agree & $\mathbf{4}$ & 1 & 3 & 3 & 5 & 48 \\
\hline Nervous & $\mathbf{3}$ & 0 & 0 & 0 & 0 & 0 \\
\hline Disagree & $\mathbf{2}$ & 0 & 0 & 0 & 3 & 6 \\
\hline $\begin{array}{c}\text { Strongly } \\
\text { Disagree }\end{array}$ & $\mathbf{1}$ & 0 & 0 & 0 & 0 & 0 \\
\hline Number of Respondents & 50 & 50 & 50 & 50 & 250 \\
\hline \multicolumn{2}{|c|}{ Actual Score } & 99 & 97 & 97 & 76 & 369 \\
\hline \multicolumn{2}{|l}{ Ideal Score } & 100 & 100 & 100 & 100 & 400 \\
\hline
\end{tabular}

$$
\% \text { Total Score }=\frac{369}{400} \times 100=92,2 \%(\text { Very Good Criteria })
$$

From the calculation of the total score in percent is 92.2 percent. Based on the total score in the above percent, it can be concluded that 92.2 percent of respondents have considered that the software developed as a prototype is reliable.

Table 5. Respondents' Responses Based on Efficiency Aspects

\begin{tabular}{|c|c|c|c|c|}
\hline \multirow{3}{*}{$\begin{array}{l}\text { Answer } \\
\text { Criteria }\end{array}$} & \multirow{3}{*}{ Weight } & \multicolumn{2}{|c|}{ Efficiency } & \multirow[t]{3}{*}{ Total } \\
\hline & & Time Behaviour & Resource Behavior & \\
\hline & & 1 & 2 & \\
\hline Strongly agree & 5 & 0 & 2 & 10 \\
\hline Agree & 4 & 46 & 47 & 372 \\
\hline Nervous & 3 & 4 & 1 & 15 \\
\hline Disagree & 2 & 0 & 1 & 2 \\
\hline $\begin{array}{l}\text { Strongly } \\
\text { Disagree }\end{array}$ & 1 & 0 & 0 & 0 \\
\hline \multicolumn{2}{|c|}{ Number of Respondents } & 50 & 50 & 100 \\
\hline \multicolumn{2}{|c|}{ Actual Score } & 76 & 77 & 153 \\
\hline \multicolumn{2}{|c|}{ Ideal Score } & 100 & 100 & 200 \\
\hline
\end{tabular}

From the calculation of the total score in percent is 75.5 percent. In the table above it appears that the respondent's response to the Efficiency aspect is quite good, although there is one respondent who does not agree with Resource Behaviour, but the score value remains on the criteria both.

\section{Overall Application Quality Level}

Table 6. Overall Application Quality Testing Results

\begin{tabular}{|c|c|c|c|c|}
\hline Aspects & $\begin{array}{c}\text { Actual } \\
\text { Score }\end{array}$ & Ideal Score & $\begin{array}{c}\text { Actual Score } \\
\text { Percentage }\end{array}$ & Criterion \\
\hline Functionality & 459 & 500 & $91,8 \%$ & Very Good Criteria \\
\hline Reliability & 293 & 300 & $97,6 \%$ & Very Good Criteria \\
\hline Usability & 369 & 400 & $92,2 \%$ & Very Good Criteria \\
\hline Effeciency & 153 & 200 & $76,5 \%$ & Good Criteria \\
\hline Total & $\mathbf{1 . 2 7 2}$ & $\mathbf{1 . 4 0 0}$ & $\mathbf{8 9 , 5 \%}$ & Very Good Criteria \\
\hline
\end{tabular}

From the calculation of the total score in percent is 89.5 percent. So based on the total score in percent, it can be concluded that the overall application quality testing results are 89.5 percent, then the prototype produced in this study falls into the criteria both.

\section{CONCLUSION}

Based on the functionality aspect, the actual score percentage gets a total value of 91.8 percent, so the prototype produced in this study is included in the very good criteria. Based on the reliability aspect, the actual score percentage *name of corresponding author

This is an Creative Commons License This work is licensed under a

Creative Commons Attribution-NonCommercial 4.0 International 
gets a total value of 97.6 percent, so the prototype produced in this study is included in the very good criteria. Based on the Usability aspect, the actual score percentage gets a total value of 92.2 percent, so the prototype produced in this study is included in the very good criteria. Based on the aspect of efficiency, the actual score percentage gets a total value of 76.5 percent, so the prototype produced in this study is included in good criteria. From the calculation of the total score in percent is 89.5 percent. So based on the total score in percent, it can be concluded that the overall application quality test results are 89.5 percent, then the prototype produced in this study is included in the very good criteria.

\section{ACKNOWLEDGMENT}

In completing this research, the author received a lot of help, prayers, and support from various parties. As a form of gratitude to Allah SWT, the author would like to express his gratitude and appreciation to:

1. Drs. Harry Sudjikianto, MM, MBA as the Chairperson of the Atma Luhur Pangkalpinang Foundation which has provided research funds for lecturers.

2. Husni Teja Sukmana, S.T, M.Sc, P.hD as the Chancellor of the Atma Luhur Pangkalpinang Institute of Science and Business who has given encouragement to fellow lecturers in research.

3. Ellya Helmud, S.Kom, M.Kom as the Dean of the Faculty of Information Technology, Atma Luhur Pangkalpinang Institute of Science and Business who has provided support for this lecturer's research.

4. Okkita Rizan. S.Kom, M.Kom as the Head of the Information Systems Study Program at the Atma Luhur Pangkalpinang Institute of Science and Business who has provided support for this lecturer's research.

5. Maxrizal, S.Pd, M.Sc as the head of the research and community service institute of the Atma Luhur Institute of Science and Business Pangkalpinang who has provided support for this research.

6. Thank you to fellow lecturers of the information systems study program at the Atma Luhur Pangkalpinang Institute of Science and Business who have provided support for this research.

\section{REFERENCES}

Budiman, E. (2016). Pemanfaatan Teknologi Location Based Service Dalam Pengembangan Aplikasi Profil Kampus Universitas Mulawarman Berbasis Mobile. ILKOM Jurnal Ilmiah, 8(3), 137-144. https://doi.org/10.33096/ilkom.v8i3.81.137-144

çimen, sabri. (2021). No 主観的健康感を中心とした在宅高齢者における 健康関連指標に関する共分散構造 分析Title.4(1), 6.

Fauzi, A. (2015). Penerapan Location-Based Service pada Layanan Informasi Budaya Indonesia di Perangkat Mobile. Faktor Exacta, 8(3), 250-260. http://journal.lppmunindra.ac.id/index.php/Faktor_Exacta/article/view/325

Imansyah, N., \& Widiastuti, S. H. (2017). Layanan Berbasis Lokasi Hotel Menggunakan Realitas Tertambah. Jurnal Sistem Informasi Bisnis, 7(2), 120. https://doi.org/10.21456/vol7iss2pp120-130

Iqbal, M. M., Isnanto, R. R., Kridalukmana, R., Komputer, J. S., Teknik, F., \& Diponegoro, U. (2015). 6Huylfh $1 \% 6$ 8Qwxn / Rndvl 3Hq \Hzddq 5Xpdk. Rv Gl.Rwd 6Hpdudqj \% Huedvlv \$ Qgurlg. 3(2), 198-206.

Jamal, M., \& Susanto, A. (2012). Penerapan Teknologi Augmented Reality Sebagaimedia Promosi Berbasis Android. Universitas Dian Nusawantoro, 1-8.

Juansyah, A. (2015). Pembangunan Aplikasi Child Tracker Berbasis Assisted - Global Positioning System ( A-GPS ) Dengan Platform Android. Jurnal Ilmiah Komputer Dan Informatika (KOMPUTA), 1(1), 1-8.

Kasih, P., \& Harini, D. (2018). Layanan Berbasis Lokasi Dalam Sistem Informasi Dan Rute Rumah Sakit Di Kota Kediri. Joutica, 3(2), 194. https://doi.org/10.30736/jti.v3i2.234

Marlinda, L. (2016). Aplikasi pencarian lokasi sekolah di wilayah cileungsi berbasis android. 324-331.

Rokhman, N., \& Nugroho, I. D. (2013). Aplikasi Pencarian Lokasi Fasilitas Umum Berbasis Foursquare APIv2 pada Sistem Operasi Android. IJCCS (Indonesian Journal of Computing and Cybernetics Systems), 7(2), 209. https://doi.org/10.22146/ijccs.3361

Services, L. (2015). Location-Based Services. 10(2), 5-9.

Susanty, W., Astari, I. N., \& Thamrin, T. (2019). Aplikasi Gis Menggunakan Metode Location Based Service (Lbs) Berbasis Android. Explore: Jurnal Sistem Informasi Dan Telematika, 10(1). https://doi.org/10.36448/jsit.v10i1.1218

Widiani, L. S., Darmawan, W., \& Ma'mur, T. (2018). Penerapan Media Film Sebagai Sumber Belajar Untuk.

*name of corresponding author

This is an Creative Commons License This work is licensed under a

Creative Commons Attribution-NonCommercial 4.0 International

License. 


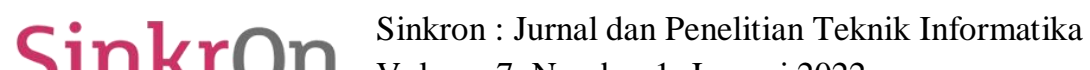

S11 Volume 7, Number 1, Januari 2022

e-ISSN : 2541-2019

DOI : https://doi.org/10.33395/sinkron.v7i1.11219

p-ISSN : 2541-044X

Factum: Jurnal Sejarah Dan Pendidikan Sejarah, 7(1), 123-132.

裕作平野, 章裕須藤, \& 和夫橋下. (2011). Location Based Serviceを用いた拡張現実アプリケーションの開発. 2(4), 73-74.

*name of corresponding author

c) (7) 5 This is an Creative Commons License This work is licensed under a Creative Commons Attribution-NonCommercial 4.0 International License. 